\title{
THE WEREWOLF AS A RELIGIOUS AND ETHNIC OTHER IN A HERZEGOVINIAN LEGEND
}

\author{
Mirjam Mencej \\ Department of Ethnology and Cultural Anthropology \\ Faculty of Arts \\ University of Ljubljana, Slovenia \\ Email: mirjam.mencej@guest.arnes.si
}

\begin{abstract}
The paper focuses on a particular legend about a wrestling match between a human and a dead werewolf, which I recorded during my fieldwork in the Croat (i.e. Catholic) community in Herzegovina in 2017. Based on the analysis of a legend about a wrestling match between a human of Catholic faith and a Muslim werewolf, I aim to show how latent inter-ethnic and inter-religious tensions in multi-ethnic and multi-religious Bosnia and Herzegovina are reflected in this legend about the restless dead. I pay particular attention to how the ethnic and religious Other is constructed in the legend, and demonstrate the prejudices against the religious and ethnic Others that are reflected in it. I argue that its main function was, and still is, first and foremost to emphasise the superiority of the narrator's religion, i.e. Catholicism, over Islam, and to serve as a warning to Catholics against abandoning their faith and converting to another religion.
\end{abstract}

Keywords: Bosnia and Herzegovina, ethnic identity, Islam, religion, the dead, vampire, werewolf

It has often been demonstrated that folklore, and legends in particular, reflects the cultural and social context within which it is transmitted (cf. Abrahams 1971; Dégh 2001: 127-128; Ellis 2003: 11-12; Fine 1985; Tangherlini 1994: 18-19, 2013: 51; Valk 2008: 169; Ward 1976). By means of folklore, community members are also able to emphasise distinctive characteristics by which their own group differs from others, and thus define, maintain, and reinforce their own distinct cultural identity (cf. Bendix \& Klein 1993; Dundes 1971; Jordan 1975; Mathisen 1993). Legends about encounters with the supernatural, and the dead in particular, are no exception in this respect. They likewise express cultural values and expectations, point out cultural stresses and conflicts, reaffirm social norms of behaviour, and react to cultural, economic, political and 
legal changes within societies (cf. Cowdell 2011: 7; Honko 1962: 118; Hornaday 2002: 71-72; Nyce \& Talja \& Dekker 2015: 86-87; Stewart 1991: 105-107; Valk 2006: 32, 35, 47). Moreover, they can also indicate social boundaries between different ethnic and religious groups, reflect the cultural views of strangers, and reveal ethnic stereotypes and hostility towards people of other ethnic and religious identities.

Bosnia and Herzegovina, where I conducted fieldwork from 2016 to 2019, is a multi-ethnic and multi-religious country which became independent in 1992, after the collapse of the former Socialist Federal Republic of Yugoslavia. There are three main ethnic groups living in Bosnia and Herzegovina: Bosniaks, Croats, and Serbs, related to the cultures of Sunni Islam, Catholicism, and Orthodox Christianity, respectively. Indeed, religion is one of the most important and persistent factors in the formation of ethnic consciousness and collective identity in the Balkans (Bringa 1995: 7; Čolović 1994: 155; Velikonja 1998: 18-22, 308) and in Bosnia and Herzegovina, religious affiliation is usually used synonymously with ethnic identity. Although nationalistic processes began taking place on the territory of the former Yugoslavia as early as the nineteenth century, they were suppressed under the socialist regime. Moreover, my interlocutors from rural areas, who lived side by side with the members of other ethnic and religious groups, more or less without exception stated that there had been no tension between them until the war broke out. Nevertheless, nationalistic tendencies again escalated in the 1980s-1990s, just before the collapse of former Yugoslavia, and reached their peak in the war that took place in 1992-1995 (cf. Velikonja 1998: 152). It should therefore not be surprising that folklore, including legends about the supernatural, inevitably expresses the changes in society and the revived and re-emphasised cultural prejudices and stereotypes of the members of other ethnic and religious communities living in Bosnia and Herzegovina.

In this paper, I will focus on one particular narration about a supernatural encounter. Specifically, I will discuss a legend about the apparition of the dead, called werewolf in the legend, which I recorded during my fieldwork in the Croat community in Herzegovina in 2017. In Bosnia and Herzegovina, the term "werewolf" (vukodlak, lit. wolf-hair) only rarely applies to a shapeshifter; instead, it much more usually applies to the restless dead. As has already been noted by a number of authors who have studied werewolves in this part of the world, the term "werewolf" among South Slavs more or less entirely correlates with the term "vampire" (vampir) (Đorđević 1953: 150; Levkievskaja 2001: 105; Pasarić 2015: 239 ff.), and as has been claimed by researchers since the beginning of the twentieth century, people in Bosnia and Herzegovina similarly 
make no distinction between the two terms (Bratić 1902; Lilek 1902: 271; cf. also Filipović 1963: 346). One and the same narrator could thus easily switch from one term to the other, even within the same narrative, or answer my question about "werewolves" with a story about "vampires", and vice versa. Likewise, the term "apparition" (prikaza, utvara, privid) is used with the same meaning, and during my fieldwork proved to be an even more frequent synonym for werewolf than the term vampire (Mencej forthcoming). At any rate, the terms werewolf, vampire, and apparition were regularly used interchangeably in my interlocutors' narratives, and people were generally not aware of any conceptual difference between them. ${ }^{1}$ They all refer to the dead who, due to their own sins and unresolved matters, or due to the community's violation of the norms, are unable to properly proceed to the other world. In this paper, however, I will not discuss the violated social norms that may have contributed to the dead's "return" among the living. Instead, I will pay particular attention to how the ethnic and religious Other is constructed in the legend, and illustrate the prejudices against the religious and ethnic Other that are reflected in it.

\section{ETHNIC AND RELIGIOUS OTHERS IN FOLKLORE}

Ethnic and religious Others, closely linked with the notion of exteriority, the space beyond the community's boundaries, are often marked by an otherworldly, supernatural quality in folklore. Indeed, the attribution of supernatural powers to foreigners, coming from outside the boundaries of "our" community, used to be so obvious that it was impossible to draw a firm line between the supernatural and (merely) ethnically different enemies (cf. Belova 2007: 339; Lindow 1995: 16, 19-21; Stewart 1991: 170). For ancient Scandinavians, for instance, Finns, Greenlanders, Saami, Ethiopians, Moors, and other foreign ethnic groups were endowed with the aura of the supernatural and were believed to have power over magic, and in more recent Nordic folklore, in addition to Saami and Finns, Gypsies and travellers (tinkers), conceived of as Others, are also ascribed supernatural powers (Lindow 1995: 11-15, 19 ff.).

The blurred boundary between the supernatural and other ethnic and/or religious groups is sometimes evident from the overlapping of their names and images. Supernatural entities are thus sometimes named after other ethnic groups, or their image informed by theirs, and vice versa. In Bulgarian folklore, for instance, armenka, literary "an Armenian woman/girl", is a name of a particular supernatural agency; another supernatural agency bears the name evreiche, i.e. "Jewish child" (Troeva 2009: 399). In Eastern and Western Slavic 
folklore, various demonic entities take on the appearance of Jews (Belova 2007: 341). In Greek folklore, a supernatural entity called arápis, pictured as a black man smoking a long pipe, obviously derives its name from the ethnic denomination of an Arab, as do arménides whose name derives from the ethnic name for Armenians. Jews in Greece, on the other hand, for instance, were closely related to the Devil and kallikantzaroi, demons that are believed to appear on earth during the dangerous period of the twelve days of Christmas (Stewart 1991: 170-171). In Scandinavian legends, plague, traditionally conceived of as an anthropomorphised supernatural entity, was occasionally personified as a Finn, and more generally pictured as a stranger, i.e. a "strange gentleman" (Lindow 1995: 19). In Kalošević in Bosnia and Herzegovina, legends describe plague in a human form, with goat's legs, coming from China (Kajmaković 1987: 215), whereas in Bulgarian folklore it is the image of a Gypsy that is linked to plague (Troeva 2009: 399). In the Posavina region in north-eastern Bosnia and Herzegovina, "Gipsy's or heretic eyes" were, on the other hand, attributed to werewolves (Lilek 1902: 269).

Representatives of oppressive political forces were particularly prone to the attribution of negative, supernatural characteristics (cf. Stewart 1991: 188). In Slovenian folklore, Ottoman Turks and Huns, who had attacked the territory of present-day Slovenia in the past, are typically demonised, and Turks are also associated with, or even equated to, the Devil (Mlakar 2019: 55-58, 64, 120). In Estonian serfdom songs, German noble landlords were typically demonised and equated with the Devil, spirits and ghosts, their helpers with demonic cannibals and their manors with hell. The terms saks, meaning German nobleman, and junkar (from "Junker", a German nobleman or aristocrat), were likewise euphemisms for the Devil. Moreover, since the German landlords had a status of nearly supernatural beings, the peasants took the same magic precautions in communication with them as they did in communication with the supernatural; for instance, warding off the anger of Germans with spells and salt (Valk 2001: 80-92). As Valk points out, "the images of demonic evil acquired a concrete embodiment in the figure of the German landlord. It is possible to speak of both the demonization of the Germans and the 'Germanisation' of the Devil" (Valk 2001: 86).

While physical distance and arrival from outside the community may play an important role for the members of another ethnic group who are attributed an aura of the supernatural, the members of a different ethnic community and/or different religious affiliation, even when living in the same community, may be informed by the same "otherness" that applies to people coming from beyond the community's boundaries. Living in our midst, people of different 
ethnic background and different religion represent the Other within, and are as such a constant source of threat to the members of different ethnic and/or religious groups. Like foreigners, they too can be ascribed supernatural abilities and powers, such as knowledge of magic, the ability to metamorphosise, etc. Throughout the history of European culture, it was very often Jews who - due to their different religion and ethnic background - were typically scapegoats, were attributed supernatural powers, and accused of carrying out magic procedures (Belova 2007: 339 ff.; Bronner 2007: 383; Bystroń 1980: 330-331; Matteoni 2008; Mlakar 2019: 108-109). The Roma were similarly considered magicians, for instance in Poland (Bystron 1980: 330-331). In Slovenian folklore they were associated with magic and additionally linked to hidden treasures and the otherworld (Mlakar 2019: 158-161). My Bosniak interlocutor (37) similarly told me that "there are Serbian, Gypsy, and Muslim sihrs, ${ }^{2}$ but Gypsy sihrs are the most dangerous!" When her husband added that Catholic sihrs count more or less for nought, she protested: "They do not count for nought, all sihrs are dangerous, but Gypsy sihrs are the worst as they are the filthiest!" (Mencej 2018: 264)

In multi-ethnic and multi-religious Bosnia and Herzegovina, the tensions and prejudices against the members of another religious and ethnic identity, living in the same country, and often in the same village, also occasionally found their expression in notions of ethnic and religious Others as supernatural Others, particularly in their post-mortem existence. In this paper, I will focus on how Muslims are constructed as ethnic and religious Others through their after-life agency as werewolves. A legend about a wrestling match between a human of Catholic faith and a werewolf of Muslim religious affiliation, told by a Catholic (Croat) narrator, seems an excellent example of how latent inter-ethnic and inter-religious tensions can be reflected in legends about the apparition of restless dead. Based on the analysis of this particular legend, I aim to demonstrate that its main function was and still is, first and foremost, to emphasise the superiority of the narrator's religion, that is, Catholicism, over Islam, and to serve as a warning to Catholics against abandoning their faith and converting to another religion. 


\section{WRESTLING WITH A WEREWOLF}

The story, the events of which allegedly occurred in the nineteenth century and which my Croat narrator assured me were all true, is actually based on a rather widespread motif, featuring in legends throughout the Balkans (cf. Banović 1928: 354-355; Đorđević 1953: 29; Lilek 1902: 269; Vuletić Vukasović 1901: 5) about a fight between a human and a (dead) werewolf (vampire). Fabulates featuring this motif are also known in Bosnia and Herzegovina. A legend from Vlasenički Kotar, for instance, tells about a peasant who "one night, upon his returning home from the town, heard a voice by the spring that sounded like an ox's. Suddenly, a vampire jumps in front of him and starts wrestling with him. The peasant defends himself, but all in vain. Finally, the vampire leaves him. Coming back home, the peasant becomes ill and after three days he is dead" (Đorđević 1953: 175). Another legend about a fight between a human and a werewolf was recorded in Herzegovina, where "the werewolf 'doesn't do any evil to anyone, he only wrestles with anyone who he meets on his way. If he beats a man, he kills him, and if a man beats him, he disappears"' (ibid.). Let me now, then, first present the legend that I recorded in a Herzegovinian village in $2017 .^{3}$

$\mathrm{I}^{4}$ : Let me tell you, now I'm gonna [tell] you! Grgić, the old one, we call him Old Grgić. We, the Grgices, are his descendants. He was, I would say, among the strongest and most prominent men. That was a time when humanity in people was important, when every word mattered. And then there was that one, Babić, I believe, a Turk, who was also... They were proud of him too. This was not long ago and nationality was not that important, they [Grgić and Babić] were something like buddies. And then on his fortieth birthday that Babic got sick and died. He died suddenly and people started to say that he turned into a werewolf. No one saw him until one night... As Grgic was often going to ..., that is, he was taking care of his oxen and horses, he was going to throw [hay] to the oxen. There was a basket in which there was hay and he [Babić] was in the basket. When he [Grgić] was just about to throw hay in it, that Babic appeared to him from the basket, as a werewolf. And then, he [Grgić] didn't... want to throw [hay on him], so he asked him to move. He [Babić] said: "No, I won't [move]. Let's wrestle!" The werewolf, that is, the one who had turned into a werewolf, challenged Grgić to a fight. Grgić said: "Come on, why, I don't want that, don't be foolish!" He [Babić] didn't give up but called to him: "Let's wrestle!"... And, they started [to wrestle], here, you saw there in the 
fields [pointing to the place where the wrestling contest took place], it happened there, and they were to wrestle. And he [Babić] was challenging Grgic to a fight, to wrestle. And they were wrestling, sometimes one was stronger, sometimes it was the other. They were [competing in] throwing stones... They took that thing that oxen used to drag - before there used to be oxen that dragged a cart - they took an oxcart, and competed in lifting the oxcart, over and over again... Sometimes Grgić was stronger than Babić, sometimes the other way around, and so on ... When they were wrestling on the ploughed land, so it goes, Grgic was stronger. That's because it had been blessed with holy water when it was being ploughed. Grgić was stronger [on the ploughed land], because he [Babić] was faithless, had no faith, he was nothing, they say. Whereas where it was not ploughed, the werewolf was stronger, they say.

And [finally] Grgić got fed up with him, as he [Babić] was challenging him [every night]. I mean, Grgić was annoyed, [the werewolf] wouldn't let him sleep, [they were] wrestling all the time. And Grgić was fed up, and he told, he told a friar about the case, how it all happened. What's to be done? During confession the friar told him: "Let's see, maybe he'll go away", [and suggested] "You should cross yourself!" But, the first time - nothing. Then, the second time, so it goes, the friar said: "Take the hawthorn, with thorns," he said, "sharpen it and stab [him]". "Stab him," [the friar] said, "while he is in the basket, but don't do it twice, only once, because God [created] us only once," he said. "God is one. Don't do it several times." And so it goes, he came with the hawthorn, while he [Babić] was in the basket. And now, [when] he [Babić] called on him to wrestle, they say, Grgić stabbed him. He [Babić] begged him: "Do it again!" He [Grgić] said: "No, God created us once, God is one!" And he didn't want to do it again. And after that nothing appeared to him anymore. They said that there were some goatskin's remains stabbed, but nobody has ever seen the werewolf again, and so Grgic defeated the werewolf, and the story has continued to live on among folk....

F: And why hawthorn, in particular?

I: Well, that's because, you know how Jesus' crown was of thorns... Well, everything is for a reason. ... That, hawthorn ... is the same as the crown of Jesus ... that crown of thorns ... it was of the hardest thorns. Jesus' crown is thorny and hawthorn is the hardest wood we have here. ... Yes, and he [Grgić] never had any problem [with the werewolf] anymore, nor has anybody else had. And nobody ever heard of him again or anything... 
Whereas before, down where his grave is, people, folks came to his grave and saw him... That is, when he came out, that is, when he was running around, that is, he was restless ... But he has never appeared to anybody in public, only to Grgić....

F: And how come Babić turned into a werewolf?

I: Well... the Turk wasn't baptized, he was nothing, I mean... first he was a Croat, then he converted to Islam. ... As that friar didn't conduct ..., that is, didn't organize a funeral or anything, they just buried him like an animal, they threw him into [a pit]...

F: Oh, wasn't he buried with a Muslim funeral?

I: No! Nothing, he wasn't buried with the ritual, they just threw him into... There, you saw the grave and everything. You know, before, many of them, these Muslims, they were all Turkicized. ${ }^{5}$ I mean, Turkicized, they gave them a piece of land, they got all the best pieces of land when they converted to Islam. Their families. I mean, if you converted to the Turkish religion [Islam], they gave you the best [land]... ...

F: And what is the reason for someone to turn into a werewolf?

I: Well, restlessness ... In the man, yes, in his soul, in everything. ... It happened to him [Babić] because... he abandoned his faith, he was Turkicized, he betrayed Christianity. That's why that happened to him! ...

F: Thank you, this was a great story!

I: This is no story! This is the truth, a real experience! Whereas stories are... (....) This is a true experience! Not like when people talk about fairies - who's gonna believe that! (53)

In spite of the widespread distribution of this motif in the legends throughout the Balkans, as noted above, the subjects in the legend as narrated by my interlocutor are not some undetermined people from the past. They are actual individuals who lived in the village and whose surnames are still known to the narrator. Grgic is the esteemed ancestor of my narrator's family, whose name is eternalised in the genealogical family tree (see Fig. 1), which I was proudly shown. In addition, the narrator and his relatives, who were present during his narration, were also able to show me the ruins of the house in which Babic lived and the grave (marked by stones) where he was buried (see Fig. 2), which they still keep intact - my interlocutor and his relatives swore that they would neither plough over it, nor ever build a house upon it. ${ }^{7}$ In accordance with the generic characteristic, the events in the legend about the wrestling match I was told about are also precisely localised. The contest is placed in a specific location at the boundary of the village where the narrator himself lived. I was even shown the meadow where the wrestling match between his ancestor and the 


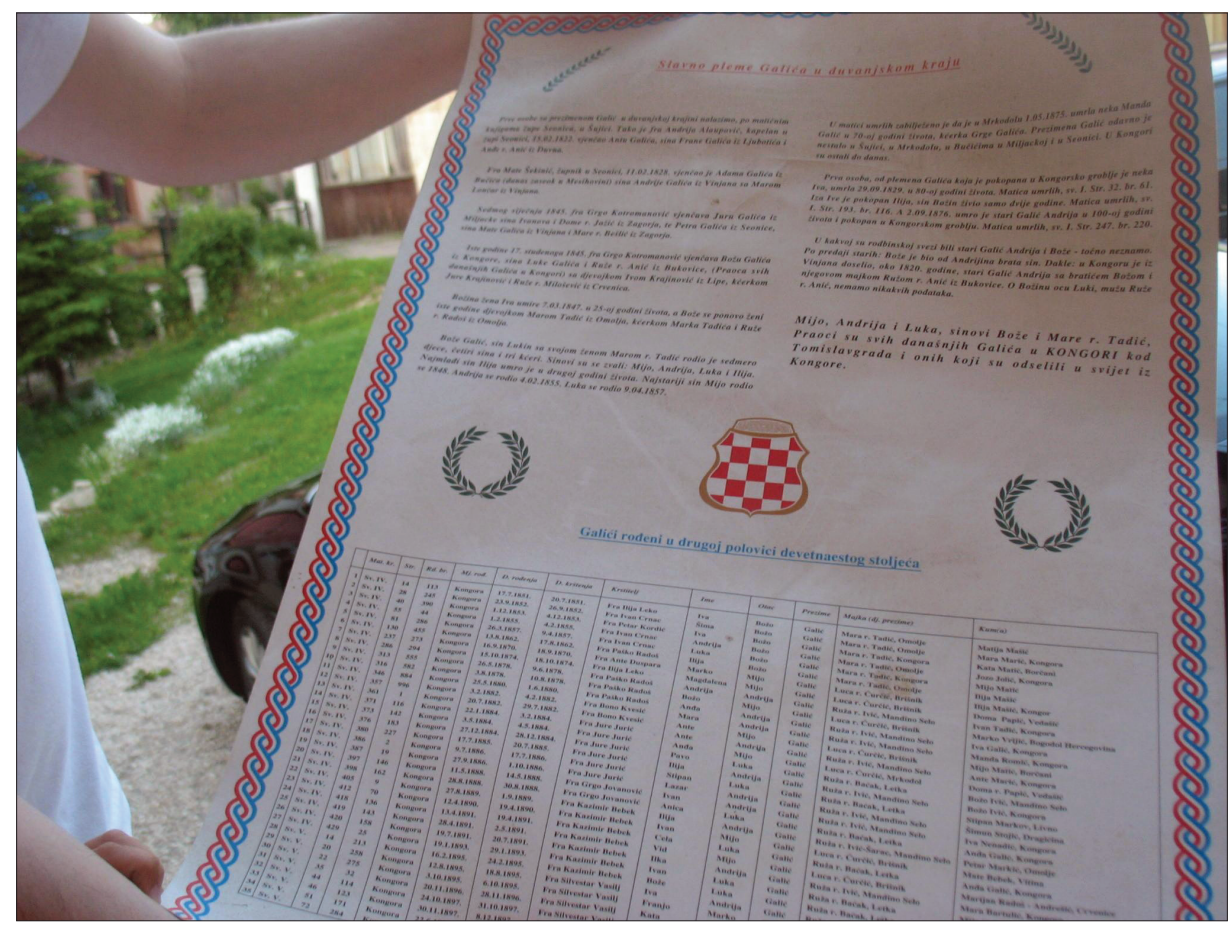

Figure 1. Grgić' genealogical family tree. Photograph by Mirjam Mencej 2017.

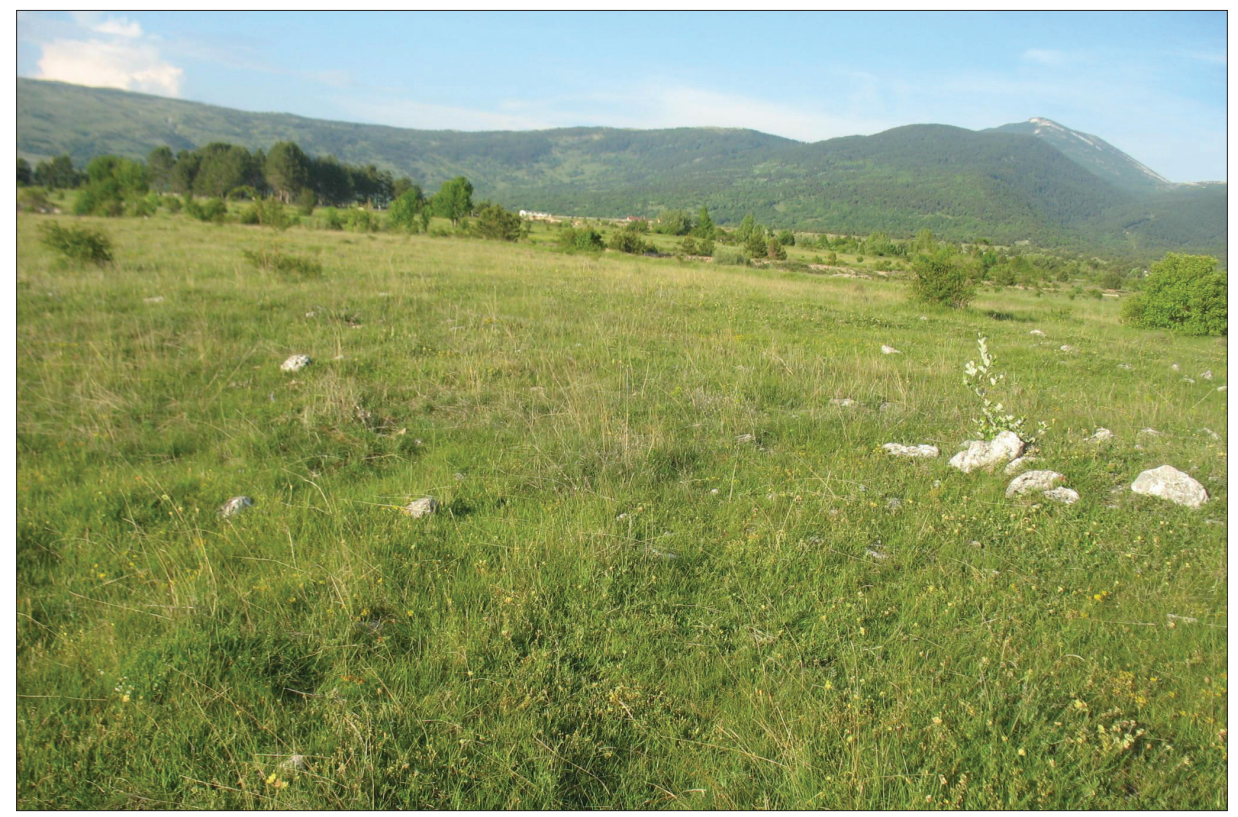

Figure 2. Stones marking Babiç' grave. Photograph by Mirjam Mencej 2017. 
werewolf took place. In the analysis of the legend that follows, I will not focus on the elements that the legend may share with other legends about a contest between a human and a werewolf, but especially on those motifs that the narrator himself introduced to the legend - the motifs by which he ultimately transformed the legend about a contest between a human and a dead werewolf into a legend about a fight between a Croat and a Bosniak, between a Catholic and a Muslim and, ultimately, between Christianity and Islam.

\section{CULTIVATED LAND VS. UNCULTIVATED LAND}

A motif of the legend that may seem insignificant at first glance refers to the precise definition of the place where the wrestling contest allegedly occurred: partly on land that was ploughed (oranica) and partly on land that was not. According to the narrative, the Catholic protagonist was winning only "as long as they were fighting on ploughed land". However, when they were fighting on uncultivated land, it was the Muslim werewolf who was winning. The narrator's explanation of why the Catholic hero was winning only while they were fighting on the ploughed land was that this was due to the power of the blessing over the ploughed field. ${ }^{8}$ Among the Catholics in Herzegovina, the blessing of the fields is considered to be an apotropaic means against all sorts of misfortunes, and it is not an uncommon practice for the Catholics in the region under research to bless their fields with holy water, and sometimes with holy salt. Moreover, the annual blessing of the fields, conducted by clerics, usually on the family's graves, aimed at ensuring the fertility of the fields and their protection from misfortune, is also a fairly commonly practiced ritual among the Catholics in Bosnia and Herzegovina (Martic 2019). ${ }^{9}$ People in this region often emphasised its power to protect them against the supernatural, fairies in particular (Mencej 2019: 170-171). Irrespective of the apotropaic power of the blessings conducted by householders themselves, as well as of the annual blessing of the fields conducted by the Catholic priests or friars, ploughed land is also considered a safe place, protected from the destructive agency of the supernatural, in the folklore of other ethnic and religious groups in Bosnia and Herzegovina. A Muslim female narrator (34) from Central Bosnia, for instance, told me a story about a revenant who rose from the grave in order to drag his lover into it too. He was able to appear to her allegedly only because she was not standing on ploughed land - "apparitions cannot appear on ploughed land", my interlocutor stressed (34). 
The opposition between ploughed and unploughed land clearly mirrors the opposition between the inner and the outer, "our" and foreign space, the human and the supernatural. Indeed, if one refers to the (somewhat problematic) dichotomy between Nature and Culture, in European traditional concepts of space the ploughed, cultivated land typically represents Culture - as opposed to unploughed, uncultivated land representing Nature (Stewart 1991: 169; Pócs 2011: 100). The motif of a human hero winning while fighting with a werewolf on ploughed land and the dead werewolf winning while fighting on unploughed land therefore implies the relation between the hero, as the representative of the world of humans, to cultivated land and Culture, whereas his werewolf opponent is related to the world of the dead, to uncultivated land, and to Nature. However, as the hero is not just any human, but a Catholic, and the dead not just any dead, but a Muslim, Culture is thus associated not just with human beings, but specifically with Catholics. Nature and wilderness, related to the dead, are, on the other hand, associated with Muslims. Ultimately, therefore, the Catholic Church is revealed to be intrinsically linked with the world of humans, cultivated space, and Culture, whereas the Islamic faith is associated with the demonic dead, uncultivated space, and wild Nature.

\section{THE MAGICAL POWER OF THE HAWTHORN}

The notion of the supremacy of Christianity over Islam is revealed in yet another motif that appears in the legend: the means of overcoming the werewolf, or, more precisely, its interpretation, suggested by the narrator. In the legend, as told by my Croat interlocutor (53), the hero Grgić appeals to a Catholic friar for help against the werewolf. On his advice, he first tries to counteract the werewolf with the power of a holy cross, the most powerful Christian symbol (Martić 2019: 95), which people also used to protect themselves against the agency of fairies (Mencej 2019: 167). When this does not help, he is advised to stab the werewolf with a hawthorn stake with thorns, but "only once", as "there is only one God" and because "God only created people once" - an instruction that obviously refers to Christian dogma. Taking this advice, the hero finally manages to overcome his werewolf adversary.

Now, stabbing the dead body with a hawthorn stake (glogov kolec) is the most common traditional means used for the annihilation of werewolves (vampires) in the Balkans (cf. Čajkanović 1994: 212-213; Đorđević 1953: 188-189, 194-195, 211-212; Dragičević 1908: 460; Kajmaković 1974: 101; Lilek 1896: 418; Schneeweiss 2005: 40). In Bosnia and Herzegovina, it is known and used 
with the same aim by the members of the Catholic, Orthodox, and Muslim communities alike. Moreover, not only is the body of the dead that is thought to have transformed into a werewolf stabbed by a hawthorn stake; the coffin and the house of the deceased are also sometimes bound by the hawthorn's thorny branches in order to prevent the dead from turning into a werewolf. Serbs from the western Bosnian region where I was doing fieldwork in 2016 would also carefully observe the grave after a funeral: if a hole appeared on its surface, they thought that the dead had transformed to a werewolf and started to wander around the village. To prevent him or her from coming out of the grave, they would take a small hawthorn branch and stab it into the hole.

In spite of the hawthorn therefore being generally considered the most powerful magical means of protection against werewolves all over the Balkans, and used by the believers of all three faiths in Bosnia and Herzegovina, my Catholic narrator explained the efficacy of the hawthorn stake over werewolves through the power of Christianity: he likened the hawthorn to Christ's crown, that is, associated its thorns with the thorns of Christ's crown. Ultimately, therefore, the narrator did not rely on "tradition" that confers the magical power upon hawthorn, but on its association with powerful symbols in Christianity. In this way he appropriated the (power of) traditional means, proper to all three ethnic and religious groups in Bosnia and Herzegovina, to testify to the power of his own group.

\section{THE FAITHLESSNESS OF OTHERS}

When the narrator talked about Babić, the Muslim, i.e. the Catholic Grgić's opponent in the fight, he referred to him as being "faithless", "without religion" - as being "nothing". Such a perception of other religious groups as not only having "bad" faith, but as being faithless, or sometimes even the opposite - worshipping diabolic spirits and performing diabolic rituals - is one of the most typical themes pertaining to the folkloric image of the Other (Belova 2007: 336, 340). In Poland, clerics of faiths other than the dominant Catholicism - like Polish Orthodox priests and Islamic imams - were sometimes believed to communicate with the Devil (Stomma 1986: 37-38). In Slovenian folklore, as Mlakar (2019: 64) argues, the notion of faithlessness and the relation with the demonic and the Devil is pushed to the extremes when associated with Ottoman Turks. From the perspective of ethnocentrism, it is thus exclusively our own ethnic group that possesses true religion - or rather, possesses religion at all. 


\section{OTHERS AS ANIMALS}

Moreover, in our legend, upon his death, Babić as a Muslim, and thus a nonbeliever from the Catholic perspective, was - as my narrator stated - simply thrown into a ditch and "buried like an animal". The association of ethnic and religious Others with animals often informs the death of believers of other religions and of other ethnic backgrounds. Greeks in Rhodes, for instance, sometimes referred to the death of a Turk with the expression "animal-died", which they explained on the grounds that "the Turks do not profess the true religion: they are 'godless' people" (Stewart 1991: 188).

Furthermore, in the legend in question, the werewolf, while looking as he did when he was alive, also exhibited animalistic features. When asked about his image, my interlocutor explained that his belly was bloated and hairy - which might point to the wolf's image, but the narrator also directly associated the werewolf's belly to a "goatskin" (mješina). ${ }^{10}$ Later on in the course of the narration, he also mentioned that when the werewolf was stabbed, all that was left of him was some goat's skin found lying on the floor. The shape of a werewolf as a bloated goatskin, full of blood, is also a rather well-known motif in traditional Bosnian and Herzegovinian folklore on werewolves (cf. Bratić 1902: 292; Filipović 1949: 211; Kajmaković 1974: 101; Lilek 1902: 269). The narrator was thus likely relying on the werewolf tradition when describing his image, but the assigning of "animal" essences, or imagining members of other ethnic and religious groups in a combined animal and human form (Belova 2007: 337, 340-341) is fairly common in folklore in general. The Catholic Poles, for instance, referred to Islam as "mare's religion", to Lutheranism as "dog's religion" and to the religion of Baptists and Jehovah's witnesses as "cat's religion" (Stomma 1986: 37). In nineteenth- and early twentieth-century Poland, the taboo against eating pork observed by Jews was explained by their origin: Jewish women supposedly originate from pigs. In the Eastern and Western Slavic traditions, Jews were generally assigned zoomorphic features. Lithuanian Poles compared their "different" smell11 to the smell of animals; they were also believed to have a tail and horns and were associated with unclean animals, and Jewish women were said to originate from swine (Belova 2007: 341, cf. 337-341; Stomma 1986: 31). Serbian politicians from the turn of the twentieth century similarly claimed that while human tails had died out long ago, Albanians retained them until the nineteenth century (Jezernik 2011: 87-88), and in South Slavic and Slovenian folklore, Ottoman (Muslim) Turks were equated with cynocephali and believed to originate from the union between a dog and a woman (Mlakar 2019: 57). In an Estonian folk song, German noblemen are pictured as "tailless dogs" (Valk 2001: 82). In the past, Scandinavians ascribed animalistic 
characteristics to people of colour: their eyes were compared to cats' eyes, their stout frame to that of a bull, and they were said to have claws like a griffin - in short, they were seen as a mixture of human and animal. Later on, Saami and Finns were ascribed the ability to change into animals, and were presented as human-animal mixtures, werewolves and man-bears, or as riding animals such as rats and snakes (Lindow 1995: 17-19).

\section{THE AFTER-DEATH SOJOURN OF OTHERS}

The proneness of people of other religious affiliation to turn into werewolves after death can be seen in the legend discussed here as well. Not only are they considered faithless per se, but their funeral is also not conducted "properly", that is, according to the correct religious rites - which, of course, are only considered as such when they belong to the religion of the narrator - and is thus considered invalid. An invalid funeral, moreover, can be the reason for the dead to be unable to progress to the other world; he or she is thus bound to become a restless dead, to turn into a werewolf/vampire and haunt the living (cf. Lawson 1964 [1910]: 375). The likeliness of people to turn into a werewolf seems even greater for people who betrayed their religion and converted to another - a deed that is considered to be one of the most severe violations of social norms. When asked about the reason for Babic to turn into a werewolf, the narrator explained without a second thought: "Well, restlessness ... In the man, yes, in his soul, in everything. ... It happened to him because... he abandoned his faith, he was Turkicized, he betrayed Christianity. That's why that happened to him!" Muslims, considered faithless from the perspective of the Christian believers, have, indeed, typically qualified as werewolves/vampires in the eyes of the Christians in the Balkans.

When writing about the Albanians (who are mostly of Islamic faith), Tomo Bratić, a Catholic ethnographer from Bosnia and Herzegovina at the beginning of the twentieth century, explained the continuing existence of werewolves among the Albanians by their "faithlessness": "It is difficult to find a werewolf in Bosnia and Herzegovina today, but they still exist in Albania nowadays, because the people there are faithless and lawless" (Bratic 1902: 293). Orthodox Christians in Bosnia and Herzegovina similarly believed that people who are baptised will not become vampires - and even if they did, they would do no harm to their family (Lilek 1899: 703). In Greece, anyone who did not belong to Orthodox Christianity, Turks in particular (who had been the oppressors in the Balkan territory for about four hundred years), was believed to turn into a vampire after death much more easily than Greeks (Đorđević 1953: 171). 
When Crete was occupied by the Turks, it was thought that every Thursday evening ${ }^{12}$, Turkish vampires transformed into "howling black and white dogs". In Greek-speaking Asia Minor, legends circulated about Turks who returned from the world of the dead in the shape of "dogs and cats" (Stewart 1991: 187-188). Similar stories about Turkish soldiers who, after having fallen in a fight with Albanians and Greek rebels, turned into vampires, circulated among Albanians in Greece. In some parts of Albania, there are stories about (only) Turks and Roma becoming vampires after death (Kreuter 2003 [2002]: 2). In Serbian folklore too, it was most often Turks that were believed to turn into vampires (Đorđević 1953: 171), yet in the Balkans, the label "Turk" usually applied to Muslims in general (Hangi 1907 [1906]: 9). According to a legend from Potomlje, Dalmatia, people suspected that a certain person had turned into a werewolf; when his grave was dug up, they saw a man sitting in his grave crossed-legged, that is, with his legs crossed "in the Turkish way" (Banović 1918: 187; Šešo 2016: 199) - clearly revealing the werewolf as a Muslim.

Werewolf narratives thus often reflect prejudices against the Muslim religion and culture among Christian believers. Moreover, Muslims are additionally degraded in legends in which they are pictured as turning into pigs or wild boars after death (posvinjiti se; lit. "to turn into a swine"). This notion obviously relates to the taboo against eating pork in Islam and a generally shared notion of swine as particularly dirty animals (due to their fondness for mud and dirty places and their rooting for food below the earth's surface) and demonic creatures (cf. Radenković 1996: 124-128). Bulgarian legends similarly relate that Turks turn into vampires in pigs' bodies after death (Troeva 2009: 399); the after-death transformation into wild boars sometimes applies only to Turks who never ate pork (Abbott 1903: 216). In the village of Slepče, in Macedonia, they say that wild boars originate from Turks who turn into vampires, which explains why the Turks do not eat pork (Momirović 1939: 97). In the Djevdjelia region in Macedonia they say that Muslims who ate pork turned into pigs, not vampires. In the region around Leskovac in Serbia, they said that every true Turk transformed into a pig after death, and every "poturčenjak" (lit. "one who turned into a Turk", i.e., the term specifically refers to people who converted to Islam) into a vampire (Đorđević 1953: 171; Schneeweiss 2005: 39).

A type of legend about a Turk who turned into a pig after death and was only recognised by the ring on its toe circulates in a rather wide region, historically invaded by the Turks. In Melnik, Bulgaria, it was recorded that "Turks who have led a particularly wicked life, when at the point of death, turn into wild boars, and the ring worn by the man on his finger is retained on one of the boar's forefeet" (Abbott 1903: 215-216). A similar narrative was published by the famous Serbian folklorist Vuk S. Karađić in the nineteenth century: 
Just as the Serbs say that people can turn into vampires, the Turks say that they turn into pigs. They tell of a certain boy who had turned into a swine; they were searching for him among the pigs, but couldn't find him until they noticed a ring on one of its forefeet. (Karađic 1966 [1818]: 608; cf. Đorđević 1953: 171-172)

According to folk legends, Đorđević writes, even the Prophet himself turned into a wild boar after death, because "something jumped over him" while his body was lying at home: ${ }^{13}$

When after some time people killed the wild boar, they found a ring on its cloven hoof which had grown into the flesh so that one could hardly notice it. This was Muhammad's ring. When Turks saw that, they took a vow never to eat pork. Even nowadays they believe that the feet of wild boars have a circle which they say ensued from that ring. (Đorđević 1953: 172)

\section{CONCLUSION}

Folklore about the werewolves as restless dead seems to be particularly appropriate to incorporate negative evaluations and prejudices of religious and ethnic Others. As demonstrated above, through subtle details introduced to the well-known fabulate about a wrestling match between a human and a werewolf, the Bosnian narrator of Croat ethnic identity, which in Bosnia and Herzegovina is intrinsically linked with Catholic religious affiliation, established the superiority of his own ethnic and religious identity over the Others with which Croats, i.e. Catholics, share the country - specifically Bosniaks (Muslims), with whom they do not even share the Christian faith, as they do with Orthodox Serbs living in Bosnia and Herzegovina.

Furthermore, narratives about ethnic and religious Others turning into werewolves after death are by no means a matter of the past among Croats. Croatian folklorist Luka Šešo, who conducted fieldwork in rural Croatia, more precisely in the Dalmatian hinterland, between 2003 and 2009, writes that most narratives about werewolves with clear distinct ethnic denominations are told by Catholics and usually directed against Muslims. A Croat (Catholic) narrator from the Biokovo region in Croatia, for instance, told him about "a certain evil man who turned into a werewolf after death and then moved to Bosnia". When asked why to Bosnia, the narrator answered: "Because such things are devilish, of Turkish origin." ${ }^{14}$ A Franciscan priest from Herzegovina similarly associated werewolves with Muslims, and also with the Orthodox, but excluded 
the Catholics: "Werewolves can only be seen by the Turkish graves, by the Orthodox graves", he affirmed (Šešo 2016: 198). ${ }^{15}$

As the Muslim werewolf in the legend discussed above was originally a Croat who later converted to Islam, the story can therefore be understood not only as reflecting latent inter-ethnic and inter-religious prejudices but also as a warning legend, demonstrating what happens to Catholics who betray their religion. While in the past they may have taken advantage of converting to Islam during their lifetime by getting better land from the Ottoman oppressors, as my Croat interlocutors often explained, punishment awaits them in the afterlife. Indeed, the fact that the legend about the wrestling match between Babic and Grgić continues to be transmitted in contemporaneity, together with all the anti-Muslim motifs that it includes, reveals that the same inter-religious antagonisms and tensions latent in nineteenth-century Bosnia and Herzegovina when this particular legend allegedly started to circulate still resonate nowadays, and that it continues to serve as a vehicle for their expression. Nevertheless, it is important to know that the accounts of the tensions and of the recent war that focus on ancient inter-ethnic hatreds are misleading. The important issue is not ethnicity as such, but, as Hammel argues, "ethnicity with a specific political history and subject to political manipulation in a context of the collapse of civil order" (2000: 29-30).

\section{ACKNOWLEDGEMENTS}

The research leading to the results presented in the paper was funded by the European Research Council under the European Union's Seventh Framework Programme (FP7/2007-2013) / ERC grant agreement No. 324214, and the Slovenian Research Agency (ARRS) under the programme Slovenian Identities in European and Global Context, and the bilateral project between Slovenia and Bosnia and Herzegovina, War as a Turning Point in Evaluating Past and Contemporary Experiences of Slovenia and the Republic of Bosnia and Herzegovina. 


\section{NOTES}

1 When discussing the topic in general, I use the term "werewolf" in this paper, but when referring to or citing what particular authors and narrators have said, I use the term used by them.

2 The Arabic word sihr means "magic" (Davies 2012: 9).

3 Throughout his narration, which lasted for about an hour, the narrator returned to the same episodes several times, offered new, more elaborate explanations to my additional questions, occasionally expanded parts of the narrative with new details that he had skipped before, etc. The text below is therefore - for the purposes of the analysis - composed of the first version of the story and its later additions. I have omitted repetitions, incomprehensible parts, explanations of various dialect words that I didn't understand, side discussions that were not related to the story, and precise descriptions of the location where the events in the narrative took place.

${ }^{4} \mathrm{I}$ in the transcripts refers to the interlocutor and $\mathrm{F}$ to the folklorist (the author).

5 The word connotes a conversion to Islam.

6 Due to the delicacy of the topic the names of interlocutors are not given, and all personal names mentioned are pseudonyms. The number in the brackets (see the list of interlocutors) indicates the number of the interlocutor in the archives. The recordings and transcripts of the interviews are being stored in the archive of Hungarian Academy of Sciences in Budapest.

7 In Bosnia and Herzegovina, graves are generally not to be disturbed. Many legends and first-person narratives warn against their disturbance or removal by demonstrating the consequences of such acts.

8 Stewart writes that in Greece, ploughed land is considered safe because it is 'crossed' by successive ploughings (1991: 169).

9 Ritual blessing of the fields is also practiced by the Orthodox community, whereas the Muslim equivalent of this ritual can be recognised in the "dova" ritual (Martic 2019: $87 \mathrm{ff}$.), likewise taking place by gravesides, usually of important Muslims such as shehids (martyrs who died for their faith) and evlijas (saints).

${ }^{10}$ Used as a water-carrying vessel.

${ }^{11}$ Olfactory markers can be used as a means of expressing cultural identity; foul odours are typically ascribed to Others. In many cultures they are understood as originating from death and associated with the Devil (Classen 1992: 140, 150-153, 159 ff.; cf. also Belova 2007: 341; Bystroń 1980: 325-326).

12 That is, the night before Friday, the most important day of the week for Muslims, when congregational prayers are held in the mosque (according to traditional beliefs, the day starts at dusk on the previous day). 
13 The most frequently stated reason for a person to turn into a werewolf/vampire in Bosnia and Herzegovina and elsewhere in the Balkans is that something (usually an animal, such as a cat or a hen) crossed over the dead body while it was lying at home, or in a grave (cf. Đorđević 1953: 167; Dragičević 1908: 458; Filipović 1949: 211; Kajmaković 1974: 101; Lilek 1896: 418; 1902: 269-270; Schneeweiss 2005: 40).

${ }^{14}$ The majority of Muslims from the former Yugoslavia live in Bosnia and Herzegovina.

15 Šešo also noticed that Catholics in his research area have recently found the following categories of people to be prone to turning into werewolves: those who have no faith, atheists, communists, and - in one case - also Orthodox, who, after the war in the 1990s (in which Croats fought against Serbs), also became Others (2016: 200, 202).

\section{REFERENCES}

Abbott, George F. 1903. Macedonian Folklore. Cambridge: University Press. Available at https://archive.org/details/macedonianfolklo00abborich, last accessed on 30 October 2019.

Abrahams, Roger D. 1971. Personal Power and Social Restraint in the Definition of Folklore. Journal of American Folklore, Vol. 84, No. 331, pp. 16-30. http://dx.doi. org/10.2307/539730.

Banović, Stjepan 1918. Vjerovanja (Zaostrog u Dalmaciji). [Beliefs. (Zaostrog in Dalmatia).] Zbornik za narodni život i običaje južnih Slavena, Vol. 23, pp. 185-214.

Banović, Stjepan 1928. Vukodlaci. [Werewolves.] Zbornik za narodni život $i$ običaje južnih Slavena, Vol. 26, pp. 347-357.

Belova, Olga 2007. The Stereotype of the "Other" within Folk Culture: An Attempt at a Formal Description. East European Jewish Affairs, Vol. 37, No. 3, pp. 335-351. http://dx.doi.org/10.1080/13501670701654532.

Bendix, Regina \& Klein, Barbro 1993. Foreigners and Foreignness in Europe: Expressive Culture in Transcultural Encounters: Introduction. Journal of Folklore Research, Vol. 30, No. 1, pp. 1-14. Available at https://www.jstor.org/ stable/3814406?seq=1\#page_scan_tab_contents, last accessed on 30 October 2019.

Bratić, Tomo A. 1902. Iz narodnog verovanja: U kotarima Nevesinje i Gacko. [From Folk Belief: In the Districts of Nevesinje and Gacko.] Glasnik zemaljskog muzeja u Bosni i Hercegovini, Vol. 14, pp. 288-295. Available at https://www.scribd.com/ document/53953064/Glasnik-Zemaljskog-muzeja-u-BiH-godina-14-knjiga-2-apriljuni-1902, last accessed on 30 October 2019.

Bringa, Tone 1995. Being Muslim the Bosnian Way: Identity and Community in a Central Bosnian Village. Princeton, New Jersey: Princeton University Press.

Bronner, Simon J. 2007. The Ritual Murder or Blood Libel Legend: A Study of AntiSemitic Victimization through Projective Inversion. Introduction. In: Simon J. Bronner (ed.) The Meaning of Folklore: The Analytical Essays of Alan Dundes. Logan, Utah: Utah State University Press, pp. 382-385. Available at https://www. jstor.org/stable/pdf/j.ctt4cgrzn.24.pdf, last accessed on 30 October 2019. 
Bystroń, Jan Stanisław 1980. Tematy, które mi odradzano: Pisma etnograficzne rozproszone. [The Themes That I Was Being Advised Against: Scattered Ethnographic Letters.] Warszawa: Państwowy Instytut Wydawniczy.

Classen, Constance 1992. The Odor of the Other: Olfactory Symbolism and Cultural Categories. Ethos, Vol. 20, No. 2, pp. 133-166. http://dx.doi.org/10.1525/ eth.1992.20.2.02a00010.

Cowdell, Paul 2011. Belief in Ghosts in Post-War England. Diss. (PhD Thesis). University of Hertfordshire. Available at https://uhra.herts.ac.uk/handle/2299/7184, last accessed on 30 October 2019.

Čajkanović, Veselin 1994. Stara srpska religija i mitologija. [Ancient Serbian Religion and Mythology.] Sabrana dela iz srpske religije i mitologije. [Collected Works on Serbian Religion and Mythology.] Vol. 5. Belgrade: Srpska književna zadruga, Beogradski izdavačko-grafički zavod, Prosveta, Partenon M.A.M.

Čolović, Ivan 1994. Bordel ratnika: Folklor, politika i rat. [Brothel of Soldiers: Folklore, Politics, and War.] Belgrade: Biblioteka XX vek.

Davies, Owen 2012. Magic: A Very Short Introduction. Oxford: Oxford University Press.

Dégh, Linda 2001. Legend and Belief: Dialectics of a Folklore Genre. Bloomington \& Indianapolis: Indiana University Press.

Đorđević, Tihomir R. 1953. Veštica i vila u našem narodnom vjerovanju i predanju. Vampir i druga bića u našem narodnom vjerovanju i predanju. [Witch and Fairy in Our Folk Belief and Legendry. Vampire and Other Beings in Our Folk Belief and Legendry.] Srpski etnografski zbornik 66. Belgrade: SANU.

Dragičević, Tomo 1908. Narodne praznovjerice (Žepče). [Folk Superstitions (Žepče).] Glasnik zemaljskog muzeja u Bosni i Hercegovini, Vol. 20, pp. 129-138, 449-466.

Dundes, Alan 1971. The Study of Ethnic Slurs: The Jew and the Pollack in the United States. Journal of American Folklore, Vol. 84, No. 332, pp. 186-203. http://dx.doi. org/10.2307/538989.

Ellis, Bill 2003. Aliens, Ghosts, and Cults: Legends We Live. Jackson: University Press of Mississippi.

Filipović, Milenko S. 1949. Život i običaji narodni u Visočkoj nahiji. [Folk Life and Customs in Visočka nahija.] Srpski etnografski zbornik LXI. Belgrade: Srpska akademija nauka.

Filipović, Milenko S. 1963. Pogledi na svet. [World-Views.] In: Ernest Grin (ed.) Lepenica: Priroda, stanouništvo, privreda $i$ zdravlje. [Lepenica: Nature, Inhabitants, Agriculture, and Health.] Posebna izdanja, knjiga 3. Sarajevo: Naučno društvo SR Bosne i Hercegovine, pp. 341-364.

Fine, Gary Allan 1985. Social Change and Folklore: The Interpretation of Social Structure and Culture. ARV: Nordic Yearbook of Folklore, Vol. 41, pp. 7-15.

Hammel, Eugene A. 2000. Lessons from the Yugoslav Labyrinth. In: Joel M. Halpern \& David A. Kideckel (eds.) Neighbors at War: Anthropological Perspectives on Yugoslav Ethnicity, Culture, and History. Pennsylvania: The Pennsylvania State University Press, pp. 19-38. 
Hangi, Antun 1907 [1906]. Život i običaji Muslimana u Bosni i Hercegovini. [The Life and Customs of Muslims in Bosnia and Herzegovina.] 2nd edition. Sarajevo: Naklada Daniela A. Kajona. Available at https://archive.org/details/ ivotiobiajimusl01hanggoog/, last accessed on 31 October 2019.

Honko, Lauri 1962. Geisterglaube in Ingermanland. FF Communications 185. Helsinki: Academia Scientiarum Fennica.

Hornaday, Aline G. 2002. Visitors from Another Space: The Medieval Revenant as Foreigner. In: Albrecht Classen (ed.) Meeting the Foreign in the Middle Ages. New York \& London: Routledge, pp. 71-95.

Jezernik, Božidar 2011. Divja Evropa: Balkan v očeh zahodnih politikov. [Wild Europe: The Balkans in the Gaze of Western Travellers.] Ljubljana: Slovenska matica.

Jordan, Rosan A. 1975. Ethnic Identity and the Lore of the Supernatural. The Journal of American Folklore, Vol. 88, No. 350, pp. 370-382. http://dx.doi.org/10.2307/538652.

Kajmaković, Radmila 1974. Semberija. Glasnik Zemaljskog muzeja u Bosni i Hercegovini. Etnologija, nova serija, Vol. 29, pp. 5-122.

Kajmaković, Radmila 1987. Narodni običaji u tešanjskom kraju. [Folk Customs in Tešanj.] Glasnik Zemaljskog muzeja u Bosni i Hercegovini. Etnologija, nova serija, Vol. 41/42, pp. 211-222.

Karađić, Vuk S. 1966 [1818]. Srpski rječnik. [Serbian Dictionary.] Belgrade: Prosveta.

Kreuter, Peter Mario 2003 [2002]. Der Vampir, ein Fremder? Ethnische Minderheiten im Vampirglauben Südosteuropas. Kakanien-revisited.at. Available at http://www. kakanien-revisited.at/beitr/fallstudie/PKreuter1.pdf, last accessed on 31 October 2019.

Lawson, John Cuthbert 1964 [1910]. Modern Greek Folklore and Ancient Greek Religion: A Study of Survivals. New York: University Books.

Levkievskaja, Elena 2001. Vampir. [Vampire.] In: Svetlana M. Tolstoj \& Ljubinko Radenković (eds.) Slovenska mitologija: Enciklopedijski rečnik. [Slavic Mythology: Encyclopaedic Dictionary.] Belgrade: Zepter Book World, pp. 61-62.

Lilek, Emilian 1896. Volksglaube und volksthümlicher Cultus in Bosnien und der Hercegovina. Wissenschaftliche Mittheilungen aus Bosnien und der Hercegovina, Vol. 4, pp. 401-492. Available at https://www.zobodat.at/pdf/Wiss-Mitt-BosnienHercegovina_4_1896_0401-0492.pdf, last accessed on 31 October 2019.

Lilek, Emilian 1899. Etnološki nabirci po Bosni i Hercegovini. A. Iz narodnog vjerovanja. [Ethnologic Gatherings in Bosnia and Herzegovina. A. From Folk Belief.] Glasnik zemaljskog muzeja u Bosni i Hercegovini, Vol. 11, pp. 699-721.

Lilek, Emilian 1902. Ethnologische Notizen aus Bosnien und der Hercegovina. Wissenschaftliche Mittheilungen aus Bosnien und der Hercegovina, Vol. 8, pp. 267-280. Available at https://www.zobodat.at/pdf/Wiss-Mitt-BosnienHercegovina_8_1902_0267-0280.pdf, last accessed on 31 October 2019.

Lindow, John 1995. Supernatural Others and Ethnic Others: A Millennium of World View. Scandinavian Studies, Vol. 67, No. 1, pp. 8-31. Available at https://www. jstor.org/stable/40919728?seq=1\#page_scan_tab_contents, last accessed on 31 October 2019. 
Martić, Zvonko 2019. Obred blagoslova polja u sakralizaciji prostora. [The Ritual of Fields' Blessing in the Sacralisation of Space.] In: Marijana Belaj \& Zvonko Martić \& Mirjam Mencej (eds.) Topografije svetoga na području Buškoga Blata. [Topographies of the Sacred on the Territory of Buško Blato.] Zagreb: Hrvatsko etnološko društvo, pp. 69-133. Available at http://www.hrvatskoetnoloskodrustvo. hr/wp-content/uploads/2019/05/Topografije-svetoga-na-području-Buškoga-Blata. pdf, last accessed on 31 October 2019.

Mathisen, Stein R. 1993. Folklore and Cultural Identity. In: Pertti J. Anttonen \& Reimund Kvideland (eds.) Nordic Frontiers: Recent Issues in the Study of Modern Traditional Culture in the Nordic Countries. Turku: Nordic Institute of Folklore, pp. 35-46.

Matteoni, Francesca 2008. The Jew, the Blood and the Body in Late Medieval and Early Modern Europe. Folklore, Vol. 119, No. 2, pp. 182-200. http://dx.doi. org/10.1080/00155870802056985.

Mencej, Mirjam 2018. Magic and Counter-Magic in Twenty-First-Century Bosnia. In: Jonathan Barry \& Owen Davies \& Cornelie Usborne (eds.) Cultures of Witchcraft in Europe from the Middle Ages to the Present. Essays in Honour of Willem de Blécourt. London: Palgrave Macmillan, pp. 249-268. http://dx.doi.org/10.1007/9783-319-63784-6_12.

Mencej, Mirjam 2019. Konstrukcija prostora putem predaja o vilama. [Construction of Space through Legends about Fairies.] In: Marijana Belaj \& Zvonko Martić \& Mirjam Mencej Topografije svetoga na području Buškoga Blata. [Topographies of the Sacred on the Territory of Buško Blato.] Zagreb: Hrvatsko etnološko društvo, pp. 135-175. Available at http://www.hrvatskoetnoloskodrustvo.hr/wpcontent/uploads/2019/05/Topografije-svetoga-na-području-Buškoga-Blata.pdf, last accessed on 31 October 2019.

Mencej, Mirjam (forthcoming 2020). Werewolves as Social Others: Contemporary Oral Narratives in Rural Bosnia and Herzegovina. In: Willem de Blécourt \& Mirjam Mencej (eds.) Werewolf Legends. Cham: Palgrave Macmillan.

Mlakar, Anja 2019. Skrivnostni tujec in demonski sovražnik: Drugi in drugost v slovenski slovstveni folklori. [Mysterious Foreigner and Demonic Enemy: Other and Otherness in Slovene Folklore.] Ljubljana: ISN, ZRC SAZU.

Momirović, Petar 1939. Etnološka građa iz sela Slepče u Srezu kruševskom. [Ethnologic Material from the Village of Slepče in Kruševo County.] Glasnik etnografskog muzeja u Beogradu, Vol. 14, pp. 96-99. Available at https://etnografskimuzej. rs/en/o-muzeju/izdavastvo/periodika/gem-14/, last accessed on 31 October 2019.

Nyce, James M. \& Talja, Sanna \& Dekker, Sidney 2015. When Ghosts Can Talk: Informant Reality and Ethnographic Policy. Journal of Ethnology and Folkloristics, Vol. 9, No. 1, pp. 81-97. Available at https://www.jef.ee/index.php/journal/issue/ view/16, last accessed on 31 October 2019.

Pasarić, Maja 2015. Dead Bodies and Transformations: Werewolves in Some South Slavic Folk Traditions. In: Willem de Blécourt (ed.) Werewolf Histories. Houndmills, Basingstoke, Hampshire: Palgrave Macmillan, pp. 238-256. 
Pócs, Éva 2011. Nature and Culture - "The Raw and the Cooked": Shape-Shifting and Double Beings in Central and Eastern European Folklore. In: Willem de Blécourt \& Christa Agnes Tuczay (eds.) Tierverwandlungen: Codierungen und Diskurse. Tübingen: Francke, pp. 99-134.

Radenković, Ljubinko 1996. Simbolika sveta u narodnoj magiji južnih Slovena. [Symbolism of the World in Folk Magic of Southern Slavs.] Belgrade: Prosveta, Balkanološki Institut SANU.

Schneeweiss, Edmund 2005. Vjerovanja i običaji Srba i Hrvata. [Beliefs and Customs of Serbs and Croats.] Transl. from German by Dubravka Hrastovec. Zagreb: Golden Marketing-Tehnička knjiga.

Stewart, Charles 1991. Demons and the Devil: Moral Imagination in Modern Greek Culture. Princeton, New Jersey: Princeton University Press.

Stomma, Ludwik 1986. Antropologia kultury wsi polskiej XIX w. [Anthropology of Culture of Polish Village in the 19th Century.] Warszawa: Instytut Wydawniczy Pax.

Šešo, Luka 2016. Živjeti s nadnaravnim bićima: Vukodlaci, vile i vještice hrvatskih tradicijskih vjerovanja. [Living with Supernatural Beings: Werewolves, Fairies and Witches in Croat Traditional Beliefs.] Zagreb: Naklada Jesenski i Turk.

Tangherlini, Timothy R. 1994. Interpreting Legend: Danish Storytellers and Their Repertoires. New York \& London: Garland Publishing.

Tangherlini, Timothy R. (ed. \& transl.) 2013. Danish Folktales, Legends \& Other Stories. Seattle \& London: University of Washington Press; Copenhagen: Museum Tusculanum Press.

Troeva, Evgenia 2009. Magical Interaction with the Other World: Dealing with Demons. Acta Ethnographica Hungarica, Vol. 54, No. 2, pp. 397-409. https://doi.org/10.1556/ AEthn.54.2009.2.10.

Valk, Ülo 2001. The Black Gentleman: Manifestations of the Devil in Estonian Folk Religion. FF Communications 276. Helsinki: Academia Scientiarum Fennica.

Valk, Ülo 2006. Ghostly Possession and Real Estate: The Dead in Contemporary Estonian Folklore. Journal of Folklore Research, Vol. 43, No. 1, pp. 31-51. http://dx.doi. org/10.2979/JFR.2006.43.1.31.

Valk, Ülo 2008. Folk and the Others: Constructing Social Reality in Estonian Legends. In: Terry Gunnell (ed.) Legends and Landscape. Plenary Papers from the 5th Celtic-Nordic-Baltic Folklore Symposium, Reykjavík 2005. Reykjavík: University of Iceland Press, pp. 153-170.

Velikonja, Mitja 1998. Bosanski religijski mozaiki: Religije in nacionalne mitologije $v$ zgodovini Bosne in Hercegovine. [Bosnian Religious Mosaics: Religions and National Mythologies in the History of Bosnia and Herzegovina.] Ljubljana: Znanstveno in publicistično središče.

Vuletić Vukasović, Vid 1901. Vukodlak. [Werewolf.] Karadić, Vol. 3, pp. 4-7.

Ward, Donald 1976. American and European Narratives as Socio-Psychological Indicators. Studia Fennica, Vol. 20, pp. 348-353. 


\section{INTERLOCUTORS}

34: female, Bosniak, b. 1938, a housewife, soothsayer and healer; Central Bosnia 37: female, Bosniak, b. 1972, a housewife; Central Bosnia 53: male, Croat, b. 1963, a technician; Herzegovina

Mirjam Mencej, $\mathrm{PhD}$, is full professor at the Department of Ethnology and Cultural Anthropology at the Faculty of Arts, University of Ljubljana, Slovenia. Her main research areas include belief narratives, vernacular religion, witchcraft, and death. mirjam.mencej@guest.arnes.si 